\title{
What Explains The Equity Risk Premium In ASEAN Countries?
}

\author{
Soo-Hyun Kim, Soongsil University, South Korea \\ Katherine Villalobos, Soongsil University, South Korea
}

\begin{abstract}
This paper aims to mainly investigate the impact of the selected macroeconomic variables such as inflation (INF), gross domestic product (GDP), foreign direct investment (FDI) and stocks traded turn-over ratio (STTR) on equity risk premium (ERP) of six major ASEAN member countries such as Indonesia, Malaysia, Philippines, Singapore, Thailand and Vietnam. Applied methods are panel pooled regression and panel vector error correction model (VECM) through the latest version of Eviews9. In the former approach, among the selected macroeconomic variables, both INF and STTR significantly and positively affect the ERP. Both periods and years show to have fixed effects as dummy variables. One cointegration has been determined among macroeconomic variables and ERP suggesting a long term equilibrium association which led to employ Panel VECM. INF denotes a significant long-run relationship with ERP and the error correction term results suggest deviation of INF is a relevant factor but not the errors of liquidity as the STTR didn't show any significant impact in the model. Granger Casuality test suggests both INF and ERP do granger causes each other in the short run. Thus, inflation is a robust factor of ERP in two different methods while the STTR is not a robust as it shows different results.
\end{abstract}

Keywords: Equity Premium; Panel Pooled Regression; Panel Vector Error Correction Model (VECM); Cointegration; Granger Casuality Test

\section{INTRODUCTION}

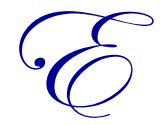

quity risk premium (ERP) which refers to the difference between returns on stocks and bonds plays an important role in the financial market. Association of South East Asian Nations or simply called ASEAN is one of the known international associations aiming to have integration on accelerating economic growth among countries members.

Most of the studies related on potential determinants affecting on equity premium are focused on the developed countries such as UK, Germany, US etc. ERP in the emerging markets are higher than the developed markets as the study of Roel of Salomons and Henk Grootveld found out after comparing the G7 and emerging countries through the method of distributional characteristics of monthly ERP. In this case, it implies that there are very few studies mainly focusing in developing countries data. In this present study, it focuses on the six major members of the organization such as Indonesia, Malaysia, Singapore, Thailand, Philippines and Vietnam which have been selected based on their stocks development and data availability, these six countries already comprise almost 95\% of the ASEAN GDP (2012 World Bank Data). This paper aims to determine which among the selected macroeconomic variables could significantly affect on ERP of six ASEAN major members. Two different methods, the panel pooled regression and panel vector error correction model (VECM) are employed and comparison of the results has been done.

Determinants of ERP in a wide range of studies are risk aversion of the investors, information uncertainty and human perceptions on different macroeconomic risk such as economic and catastrophic risks. Mehra and Prescott (1985) had questioned the consistency of general conventional theories, as the estimated ERP's were too high. And they coined this term as equity risk premium puzzle (ERPP). Many general theories attempt to explain possible reasons of this puzzle both risk and non-risk based explanations. Some of these risk-based explanations are alternative preference structure (Epstein and Zin 1991), Habit Formation (Constantinides, 1990), Resolution (Abel ,1990 and Campbell, 2001), the Campbell and Cochrane Mechanism (Campbell and Cochrane (1999), Idiosyncratic and Uninsurable 
Income Risk (Constantinides and Duffie, 1996), models including a disaster state and survivorship bias (Rietz, 1998 and Barro, 2006), Generalized Disappointment, (Gul Routledge, 1991 and Zin, 2004) etc. On the other hand, non-risk based general theories are the borrowing constraints (Constantinides et al., 2002), choice of riskless asset (Bansal et.al, 1996), effect of government regulations and rules (Mehra and Presscott, 2003), taxes (McGrattan and Presscott 2003) and agent heterogeneity and intermediation costs (Mehra and Presscott, 2008b).

There might be a lot of general theories explaining on ERP but only few macroeconomic variables have been empirically tested to determine their direct impact on it. This is because most of the previous studies are focusing on the empirical research on the stock's market return and not on the risk of equity premium. Study of Ramaprasad et.al (2011) and Karthik et al. (2011) suggests inflation has significant contribution on the equity premium while Samira Westlund et al. (2011) concluded GDP's projected growth could help to determine the equity premium. Other studies such as of Tarun et al (2001) found out trading activity could relevantly affect the expected stock returns. A research paper focused in Croatia shows stock market can significantly affect on the FDI in the country (Vladimier et al., 2012) while the vice versa is found out true in the India's stock market (R. Karthik, Dr. N. Kannam, 2011).

In this study, selected factors of macroeconomic variables such as inflation (INF), gross domestic product (GDP), foreign direct investment (FDI) and stocks traded turn-over ratio (STTR) are regressed to equity risk premium through panel pooled regression and found out that among the four variables, only inflation and stocks traded turnover ratio can significantly affect ERP. These macroeconomic variables have been chosen based on the existing previous related studies affecting on the ERP. Same with the first applied method, panel VECM also suggests relevant contribution of inflation as its deviation can significantly affect on ERP. However, STTR which is simply the liquidity didn't indicate a profound impact in the model. Before conducting the latter method, these variables' stationary is tested first and indicates all the series are integrated at I (1) and it has found out through Johansen test that one cointegration exists among these variables. Granger Casuality test shows both INF and ERP do granger cause each other. The latter and FDI also show granger cause affect on GDP which has granger cause on INF. Hence, inflation is a robust macroeconomic indicator significantly affecting on ERP. Research contribution of this study is mainly on the different method approach and the usage of international data of six ASEAN major members.

\section{REVIEW OF RELATED LITERATURE}

This section discusses general theories on determinants of equity risk premium, equity risk premium puzzle and related studies of different macroeconomic variables affecting equity risk premium.

\section{General Theories on Equity Risk Premium}

Risk aversion of investor is the most critical determinant of the equity risk premium. It has direct relationship with the ERP, as investors becoming more risk averse, ERP tends to get higher, and as risk aversion falls, ERP will decline. However, it is important to note that risk aversion varies across different investors, thus the collective risk aversion is the one influencing ERP. Risk aversion is affected by various factors such as investor age and preference for current consumption.

Information by individual firms could relevantly affect on the ERP. Reports on the volatility of the earnings and cash flows led to have risk in the underlying economy. Having more access to information means higher confidence and lower risk premiums. Lau, Ng and Zhang (2011) analyze at time series variation in risk premiums of 41 countries and suggest that countries having more information revelation and measured with a range of proxies, have less volatile risk premiums and that the significance of information is heightened during 1997 Asian financial crisis and the 2008 Global banking crisis. However some studies argue that relationship between ERP and information is complicated. There is a need to figure out on what the information tells about future earnings and cash flows, in this case, providing more information regarding on the last earnings may likely lead to more uncertainty. Example of this is the study of Yee (2006) claiming an indirect relationship wherein ERP should increase if the earnings quality decreases and vice versa. 
Catastrophic risk can attribute on ERP's decline due to sudden dramatic fall down of investors wealth investment. Even though occurrence of catastrophic events would be low, they cannot be ruled out since their risk affect will be reflected on ERP. Studies of Rietz (1998) presents evidence the possibility of catastrophic events to explain higher ERP while Barro (2006) suggests an economic depression which leads to a decline of economic output can impact on ERP. Disaster events have six years average length according to study of Barro et al. (2009) and which half of that in the short run effect is reversed in the long run. They claim that investors would require at least $7 \%$ of ERP in order to compensate the risk from these disaster events.

Human behavior and their irrationality can be one of the possible determinants of ERP. Modigliani and Cohn (1979) claim that having low equity values in the period of late 1970's were in fact due to being inconsistent of the investors on dealings with inflation in relation on their investments.

\subsection{Equity Risk Premium Puzzle}

Mehra and Prescott (1985) had argued that observed ERP's are not consistent with the financial conventional theories and have estimated historical premiums about $6 \%$ were too high and eventually termed this phenomenon as equity risk premium puzzle (ERPP). They suggest investors would have implausibly high risk-aversion to justify these premiums. Many studies attempt to give explanations both based on risk or non-risk reasons on this puzzle.

Study of Epstein and Zin (1991) suggested that Alternative Preference Structure Theory could explain the ERPP. This means modifying the conventional time and state separable utility function and the coefficient of risk aversion is linked to the elasticity of intertemporal substitution. Constantinides (1990) claims Habit Formation can have relevant contribution on the ERP due to the fact that utility is affected by both present and past consumption. Other theory is the Resolution where in asset returns and the growth rate of consumption are mutually log-normally distributed in both the standard time additive case and the Joneses (Campbell, 2001) while Abel (1990) suggests that gross returns will be lognormal if the consumption is log-normally distributed. Campbell and Cochrane (1999) have their own theory of Mechanism named after them wherein the process on an external habit $\mathrm{X}_{\mathrm{t}}$ and a period utility function of the simple, Constant Relative Risk-Aversion (CRRA). Idiosyncratic and Uninsurable Income Risk Theory by Constantinides and Duffie (1996) explains periods with repeated and large uninsurable idiosyncratic income shocks are associated with both dispersed cross-sectional distribution of the household consumption growth and low stock earnings. Rietz (1988) and Barro (2006) suggest through their Models Incorporating a Disaster State and Survivorship Bias that risk free rate is much lower than the earnings on the equity security. Gul (1991) and Routledge and Zin (2004) conclude that according to behavioral models, agents are not totally rational. Prospect theories by Barberies et al. (2001) state investors gain their satisfaction not only from their period real consumption but also from the equity portfolio gains and losses related to a plausible benchmark. Lastly is the Generalized Disappointment Aversion explaining that dissatisfaction aversion preferences have a higher satisfaction on results of disappointment Kahneman and Tervsky (1979).

For the non-risk based explanations of the ERPP, according to Constantinides et al. (2002) borrowing constraints could contribute on its puzzle due to its correlation of equity income with consumption varying over the life cycle of an individual and same with the asset's attractiveness. Bansal and Coleman (1996) claims liquidity as one of the general theories on the choice of riskless asset, indicating assets other than money could play a key feature through managing transactions. Another one is related on Transaction Balances by McGrattan and Presscott (2003); Mehra and Presscott $(2007,2008 \mathrm{a}, \mathrm{b})$ which is suggesting long dated treasury securities probably underestimate the marginal rate of intertemporal substitution of consumption. Effect of government regulations and rules has been also considered as one of the possible explanations of the puzzle wherein Mehra and Prescott (2003) concludes that government can pursue regulatory policies that will turn out to have negative interest rates over an extended period of time. Pastor and Veronesi (2011) also support the argument that government policies uncertainty can attribute to higher ERP. In addition, McGrattan and Presscott (2003) suggest taxes can relevantly explain the phenomenon of unexplainable highness of the ERP through its impact on the equity returns. Lastly, having the agent heterogeneity and intermediation cost through the differences of the strength of the bequest purpose could likely be the possible cause of the puzzle. 


\subsection{Macroeconomic Variables Affecting Equity Risk Premiums}

Most of the previous studies actually focus on the impact of the macroeconomic variables on the stock returns and only few studies conducted direct magnitude affect test on the equity risk premium.

Inflation as one of the macroeconomic variables, shows to have significantly affect on equity premium in the studies of Ramaprasad et.al and R. Karthik et al (2011). In their study, inflation fluctuates on the three different regimes such as low volatility, average volatility and high volatility. Brandt and Wang (2003) claim that news on inflation can take over news on risk premiums. They showed evidence of the positive relationship between the two variables, the equity risk premiums be likely to increase if the inflation is higher than predicted. And this tends to decrease if the inflation is lower than projected. In the present study, inflation is hypothesized as one of the macroeconomic variables that could possibly impact on ERP.

Projected growth of gross domestic product (GDP) has shown a relevant impact on the stock market return (Samira et.al, 2011) while in this paper, the historical GDP is employed to be one of the independent variables. Lettau, Ludwigson and Wachter (2007) connect varying equity risk premiums to changing volatility in the real economy of United States. In particular, they feature that the lower equity risk premiums of the 1990s reduced instability in real economic variables including GDP growth.

Tarun et al. (2001) has found out that volatility of trading activity, a proxy for liquidity variable, can significantly affect on the expected equity returns. Baekart, Harvey and Lundblad (2006) conclude that differences in both equity returns and risk premiums across emerging markets can be partially caused by differences in liquidity across the markets. Gibson and Mougeot (2002) analyze U.S. stock returns from 1973 to 1997 and attributed that liquidity is a significant factor of the overall equity risk premium and its impact changes over time Due to limitation of data availability in the present study, the stocks traded turnover ratio (STTR) is selected as one of the factors and also used as a proxy for liquidity affecting on equity premium.

Lastly, two different studies showed that Foreign Direct Investment (FDI) and the stock market can both meaningfully influence each other. In Croatia, it suggests that stock market can give a relevant contribution and can boost FDI. A reciprocal condition has been found out by Karthik (2011) indicating that it is the FDI affecting the stock market's development. Meanwhile this study focuses on the impact of FDI on the equity premium among the six major ASEAN countries. Thus, macroeconomic variables have been selected based on these related studies and use ERP as the main dependent factor in this paper.

\section{RESEARCH DATA AND METHODOLOGY}

This section discusses on how the data have been collected, how panel pooled regression quantify the effect of the selected macroeconomic variables on equity premium and how procedures of the Panel VECM have been employed.

\section{Data}

The used data in this paper are downloaded from the website of the world statistics organization such as inflation (INF), foreign direct investment (FDI), gross domestic product (GDP) and stocks traded turned over ratio (STTR), a proxy for liquidity from the year 1995-2013 except of the equity risk premium which is the dependent variable. This is because Equity Risk Premium (ERP) is calculated as the difference between real stock return and real risk free rate return. 
Table 1. Equity Risk Premium of ASEAN six major countries

\begin{tabular}{l|c|c|c|c|c|c}
\hline YEAR & JCI & FBMKLCI & PSE & STI & SET & VNINDEX \\
\hline $1995-1996$ & 183.75 & 56.38 & 65.12 & N/A & -0.13 & N/A \\
\hline $1996-1997$ & 108.38 & -43.92 & 23.69 & N/A & -42.96 & N/A \\
\hline $1997-1998$ & 232.75 & 31.49 & -1.79 & N/A & 33.83 & N/A \\
\hline $1998-1999$ & 166.17 & 52.99 & 47.51 & N/A & 44.78 & N/A \\
\hline $1999-2000$ & 42.62 & 7.96 & -9.05 & -7.83 & -35.95 & N/A \\
\hline $2000-2001$ & 83.96 & 16.60 & 1.02 & -10.24 & 34.46 & -10.10 \\
\hline $2001-2002$ & 78.70 & 11.45 & 3.77 & -14.74 & 34.68 & -7.67 \\
\hline $2002-2003$ & 104.37 & 37.14 & 10.55 & 37.02 & 98.08 & 44.49 \\
\hline $2003-2004$ & 91.66 & 32.43 & 39.18 & 29.94 & 7.52 & 36.46 \\
\hline $2004-2005$ & 73.23 & 20.78 & 25.51 & 23.83 & 28.82 & 33.03 \\
\hline $2005-2006$ & 93.00 & 34.11 & 16.16 & 34.94 & 12.13 & 42.56 \\
\hline $2006-2007$ & 71.25 & 37.69 & 30.11 & 31.58 & 31.89 & 35.76 \\
\hline $2007-2008$ & -37.96 & -32.98 & -34.61 & -58.50 & -54.35 & -29.30 \\
\hline $2008-2009$ & 71.22 & 28.21 & -20.73 & 51.95 & 46.47 & 56.60 \\
\hline $2010-2011$ & 43.50 & 20.27 & 16.55 & 9.70 & 38.44 & 20.22 \\
\hline $2011-2012$ & 4.54 & 4.59 & -5.83 & -17.91 & 0.50 & 3.56 \\
\hline $2012-2013$ & 4.08 & 4.28 & -5.76 & 13.41 & 22.99 & 19.61 \\
\hline Average & 83.25 & 18.79 & 11.85 & 9.47 & 17.72 & 20.44 \\
\hline Se & 66.78556 & 26.40332 & 25.2581 & 30.25502 & 37.19281 & 26.12468 \\
\hline
\end{tabular}

ERP needs set of data to be computed such as stock index per each country, risk free rate return, Consumer Price Index (CPI) and consumption expenditure per capita growth rate. Stock index per each country except Philippines is collected from Power Sector Assets and Liabilities Management Corp. (PSALM). The Philippine data both for the stock index and top firms are gathered from the Philippine Stock Exchange Library.

Table 2. Summary of ASEAN Countries' Stock Index

\begin{tabular}{l|c|c|c}
\hline \multicolumn{1}{c|}{ Country } & Stock Code & Period & Source \\
\hline Indonesia & JCI & $1995-2013$ & PSALM \\
\hline Malaysia & $F B M K L C I$ & $1995-2013$ & PSALM \\
\hline Philippines & $P S E i$ & $1995-2013$ & PSE Library \\
\hline Thailand & $S E T$ & $1999-2013$ & PSALM \\
\hline Singapore & $S T I$ & $1999-2013$ & PSALM \\
\hline Vietnam & VININDEX & $2000-2013$ & PSALM \\
\hline
\end{tabular}

Stock index per each country is the index of aggregate value produced by combining several stocks or other investment vehicles together and expressing their total values against a base value from a specific date in the respective country. Having the said value, stock market return is accounted for analysis. This is the market index from to $t+1$ but these returns are not the real returns, these are just simply the nominal returns. For this case, these returns have been adjusted through the inflation factor. Theoretically, the dividend should be incorporated in calculating the market return, but in here, it is not considered due to insufficient data. The statistical lag is used and dividend return over the same period of time has not been included. Thus, it is assumed that the dividend was not paid within the sample period. It is believed that the overall impact of the dividend payments would be ignorable since it would have been very small. The equation shows the calculation of the real return on equity. 


$$
R_{t+1}=\operatorname{Ln}\left(\frac{I_{t+1} / C P I_{t+1}}{I_{t+1}}\right)
$$

Where:

$$
\begin{aligned}
& R_{t+1}=\text { real rate on equity in the period } t+1 \\
& I_{t+1} \text { and } I_{t}=\text { index value at time } t+1 \text { and } t \\
& C P I_{t+1}=\text { inflation deflator in the period } t+1
\end{aligned}
$$

Moreover, the risk free rate which is a nominal risk free rate. For this case, it has also needed to be a Real Annual Risk Free Rate of Return. So, this equation below shows on how to obtain it.

$$
R F_{t+1}=r f_{t+1}-\left(C P I_{t+1}-C P I_{t}\right) / C P I_{t}
$$

Where:

$$
\begin{aligned}
& r f_{t+1}=\text { nominal rate of return } \\
& C P I_{t+1} \text { and } C P I_{t}=\text { Consumer price index at time } t+1 \text { and } t \\
& R F_{t+1}=\text { real risk free rate of return }
\end{aligned}
$$

For the data of household consumption expenditure, it refers to the market value of all goods and services such as durable products bought by the households. In the expected data of the consumption, it focused on the consumption per capita indices. The series of this is to be adjusted into real terms through dividing with consumer price index (consumption deflator series).

$$
C I_{t+1}=\frac{V_{t+1}}{V_{t}} / C P I_{t+1}
$$

Where:

$$
\begin{aligned}
& C I_{t+1}=\text { consumption index of period } t+1 \\
& V_{t+1} \text { and } V_{t}=\text { consumption value in the period of } t+1 \text { and } t \text { in absolute terms } \\
& C P I_{t+1}=\text { inflation deflator for period } t+1
\end{aligned}
$$

\subsection{Panel Pooled Regression}

Panel data is employed in the panel pooled regression which is also known as the longitudinal or cross sectional timeseries data. This is the set of data in which the behavior of entities are examined across time. In this study, the entities refer to the six major ASEAN members.

The equation below shows the panel pooled regression equation and this has been employed using the latest software Eviews 9.

$$
E R P_{t}=\alpha+\beta_{1} G D P+\beta_{2} I N F+\beta_{3} F D I+\beta_{4} S T T R+\epsilon_{t}
$$

Where:

$E R P$ - equity risk premium

$G D P$ - gross domestic product

$I N F$ - inflation

FDI- Foreign Direct Investment

STTR- stocks traded turnover ratio

$\epsilon_{t}=$ error term 
This method is used to determine the magnitude effect of selected macroeconomic variables on equity premium among the six major ASEAN countries. The periods and each cross sectional countries as dummy variables are also included in the analysis using fixed effects specifications. This is to find out whether there is fixed effects per each period and per each selected countries. Then the equation for the fixed effects model is as follows:

$$
Y_{i t}=\beta_{1} X_{i t}+\alpha_{i}+\epsilon_{i t}
$$

Where:

$\alpha_{i}=(\mathrm{i}=1 \ldots . . \mathrm{n})$ unknown intercept for each country specific intercepts (entity)

$Y_{i t}=$ dependent factor where $\mathrm{i}=$ entity and $\mathrm{t}=$ time

$X_{i t}=$ represents one independent variable

$\beta_{1}=$ coefficient of the first independent variable

$\epsilon_{i t}=$ error term

According to study of Stock and Watson (2003), the main idea on performing fixed effects model is that when there is the presence of unobserved variable which does not vary over time, then any variation on the dependent variable must be due to the impact other than these fixed characteristics.

To add time effects of model, the equation below represents the time and country fixed effects regression model.

$$
Y_{i t}=\beta_{0}+\beta_{1} X_{1, i t}+\cdots+\beta_{k} X_{k, i t}+Y_{2} E_{2}+\cdots+Y_{n} E_{n}+\delta_{2} T_{2}+\cdots+\delta_{t} T_{t}+\epsilon_{i t}
$$

Where:

$$
\begin{aligned}
& Y_{i t}=\text { dependent variable }(\mathrm{i}=\text { country; } \mathrm{t}=\text { time }) \\
& X_{k, i t}=\text { independent variables } \\
& \beta_{k}=\text { coefficient of the independent variables } \\
& \epsilon_{i t}=\text { error term } \\
& E_{n}=\text { the country n, given that they are binary dummies } \mathrm{n}-1 \\
& Y_{2}=\text { coefficient of the binary regressors (countries) } \\
& T_{t}=\text { time of dummy variables, thus } \mathrm{t}-1 \text { for the time periods } \\
& \delta_{t}=\text { coefficient for the dummy time regressors }
\end{aligned}
$$

In this equation, it denotes that controlling for time effects whenever special events such as financial crises and global crises and unexpected variation may affect the results of the variable.

\subsection{Procedures on Panel Vector Error Correction Model (VECM)}

The Panel Vector Error correction model is an advanced model of Panel Vector Autoregression model (VAR) which is employed if the variables are non-stationary at level but become stationary after the first difference or integrated at the same order. Also, if these variables found out to have cointegration or the long-run relationship through Johansen test, the VECM approach can be performed. In this case, the error correction term should be included in the VAR, then the model which is the restricted VAR turns to be VECM. Eviews9 is used to perform this analysis, first part is on the cointegration equation and followed by the error correction term's table per each variables.

Each variable has an equation in the error correction term explaining its evolution based on its own lags and the lags of the other model variables. The VECM modeling requires no much knowledge about the forces influencing a variable as structural models with simultaneous equations: The only prior knowledge required is a list of factors that can be hypothesized to have influence to each other in the long run.

Thus the procedure are as follows: testing the stationarity of the series, determining the existence of cointegration equation through Johansen Cointegration test, employing finally the panel VECM. Other test is the Granger casual test for determining the short-run relationship among variables. 


\subsubsection{Stationary Test}

The stationary of the series is very important since it can affect the behaviour of the variables. For instance, if $\mathrm{x}$ and $\mathrm{y}$ series have non-stationary random processes (integrated), then modelling this relationship in simple OLS will eventually tend to have spurious regression.

Mean and variance are the statistical characteristics of the time series over time, and if these both terms are constant over time, the series is stationary process which is not a random walk or has no unit root. On the other hand, the series is non-stationary process if it has random walk or unit root. One of the ways to make the series stationary is the differentiation. In differencing series through differential operations will generate other sets of data such as the first differenced values, the second-differenced values and so on.

$$
\begin{aligned}
& \text { x level } x_{t} \\
& \text { x } 1 \text { st -differenced value } x_{t}-x_{t-1} \\
& \text { x 2nd- differenced value } x_{t}-x_{t-2}
\end{aligned}
$$

The series is in integrated order $\mathrm{O}$ if the series is already stationary without differencing. Otherwise, it will I (1) if it is stationary at first differences or it is integrated in order (1).

\section{3-2 Johansen Cointegration Test}

This test aims to determine whether the cointegration exists among the variables. Two different tests are used such as Maximum Eigenvalue test and Trace test. The first test is testing the null hypothesis related on $r$ cointegration against the alternative $r+1$ cointegration relations wherein $r=0,1,2,3 \ldots n-1$. Equation below shows on this test is computed.

$$
L R_{\max }(r / n+1)=-T^{*} \log (1-\lambda)
$$

Where:

$\lambda=$ maximum eigenvalue

$\mathrm{T}=$ sample size

Moreover, the second test of Trace statistics tests the null hypothesis of $r$ cointegrated against with the $n$ cointegrated relations. In here $\mathrm{n}$ refers to the number of factors included in the system for $\mathrm{r}=0,1,2,3 \ldots \mathrm{n}-1$. The equation of this test is presented below.

$$
L R_{t r}(r / n)=-T^{*} \sum_{i=r+1}^{n} \log \left(1-\lambda_{i}^{\tilde{i}}\right.
$$

In some cases, both of these tests can produce different results, but the more preferred result is the one accounted from the Trace test.

\section{3-3 Panel Vector Error Correction Model (VECM)}

After detecting the existence of the cointegration, this suggests that there is a long-term equilibrium association among the series of variables. This denotes of application of VECM in order to find out the short run properties of the cointegrated series. The following equation shows the regression equation form of the VECM. 


$$
\begin{aligned}
& \Delta Y_{t}=a_{1}+p_{1} e_{1}+\sum_{i=0}^{n} \beta_{i} \Delta Y_{t-1}+\sum_{i=0}^{n} \delta_{i} \Delta X_{t-1}+\sum_{i=0}^{n} \gamma_{i} Z_{t-1} \\
& \Delta X_{t}=a_{2}+p_{2} e_{i-1}+\sum_{i=0}^{n} \beta_{i} Y_{t-1}+\sum_{i=0}^{n} \delta_{i} \Delta X_{t-1}+\sum_{i=0}^{n} \gamma_{i} Z_{t-1}
\end{aligned}
$$

In here, the number of cointegrating vectors are shown through the VECM cointegration rank. This is denoting for example a rank of two having two linearly independent combinations of the non-stationary factors will be stationary. The short term fluctuations will be indicated by the negative and significant coefficients of the error correction model. This means that the variations in the short run between independent and dependent variables will lead to have higher propability of the stable long run relationship among the variables.

\section{3-4 Granger Casuality Test}

This test shows on which variable granger other variables and vice versa. This can be expressed by the following equations:

$$
\begin{aligned}
& Y_{t}=a_{0}+a_{1} Y_{t-1}+\cdots+a_{i} Y_{t-1}+\beta_{1} X_{t-1}+\cdots \beta_{i} X_{i-1}+\mu \\
& X_{t}=a_{0}+a_{1} X_{t-1}+\cdots+a_{i} X_{t-1}+\beta_{1} Y_{t-1}+\cdots \beta_{i} Y_{t-1}+\mu
\end{aligned}
$$

Where:

$$
\begin{aligned}
& \text { Subscripts }=\text { time periods } \\
& \mu=\text { noise error } \\
& 0=\text { constant parameter of growth rate of } Y
\end{aligned}
$$

The trend in these variables indicate as general movements of the cointegration between $\mathrm{X}$ and $\mathrm{Y}$ following the unit process. Two tests can be applied, the first one is examining the null hypothesis whether $\mathrm{X}$ does not Granger-cause $\mathrm{Y}$ and the second is the vice versa. Three results can be expected in this test such as unidirectional causality, bidirectional causality and no causality existence. Unidirectional casuality refers if either one of two variables on the null hypothesis is rejected. On the other hand, the bidirectional causality occurs when both of the null hypotheses are rejected. Lastly, there is no causality if both hypotheses are accepted.

\section{RESULTS AND ANALYSIS}

This section discusses the results and analyses of the two different methods such as panel pooled regression and panel vector error correction model on determining the selected macroeconomic variables impacting on equity premium.

\section{Panel Pooled Regression's Results and Analysis}

Table 3. Results of Panel Pooled Regression

\begin{tabular}{l|c|c|c}
\hline \multicolumn{1}{c|}{ Variable } & Coefficient & Std.Error & t-statistic \\
\hline $\mathrm{c}$ & -3.695213 & 9.174049 & -0.402790 \\
\hline GDP & -0.784497 & 1.444797 & -0.542981 \\
\hline INF & $3.028432^{* * *}$ & 0.566196 & 5.348734 \\
\hline FDI & -0.189726 & 1.188475 & -0.159638 \\
\hline STTR & $0.400914^{*}$ & 0.146623 & 2.734319 \\
\hline
\end{tabular}

Table above shows the summary of the statistical results of panel pooled regression. It can be seen both inflation and STTR have positively significant impact on equity premium at 1 percent and 5 percent level of significance.

On the other hand, GDP and FDI show negatively irrelevant effect on the equity premium. For further analyses, periods as dummy variables have also been employed. 
Table 4. Fixed Effects on Periods as Dummy Variables

\begin{tabular}{c|c}
\hline Period & Coefficients \\
\hline $1995-\mathrm{C}$ & 116.9898 \\
\hline $1996-\mathrm{C}$ & 42.83329 \\
\hline $\mathbf{1 9 9 7 - C}$ & $\mathbf{- 2 5 . 6 3 7 1 6}$ \\
\hline $1998-\mathrm{C}$ & -13.27450 \\
\hline $1999-\mathrm{C}$ & 33.27955 \\
\hline $\mathbf{2 0 0 0}-\mathrm{C}$ & $\mathbf{- 1 8 . 5 5 8 2 9}$ \\
\hline $2001-\mathrm{C}$ & -3.381062 \\
\hline $2002-\mathrm{C}$ & -2.894869 \\
\hline $2003-\mathrm{C}$ & 35.73164 \\
\hline $2004-\mathrm{C}$ & 19.57055 \\
\hline $2005-\mathrm{C}$ & 9.337097 \\
\hline $2006-\mathrm{C}$ & 12.34570 \\
\hline $2007-\mathrm{C}$ & 8.194573 \\
\hline $\mathbf{2 0 0 8}-\mathrm{C}$ & $\mathbf{- 8 8 . 0 9 5 3 4}$ \\
\hline $2009-\mathrm{C}$ & 1.528799 \\
\hline $2010-\mathrm{C}$ & -2.224619 \\
\hline $\mathbf{2 0 1 1}-\mathrm{C}$ & $\mathbf{- 3 3 . 8 8 0 3 0}$ \\
\hline $2012-\mathrm{C}$ & -8.202113 \\
\hline
\end{tabular}

Fixed effects of the periods in the table indicate deviations of each year from the overall intercept rather than an individual intercept. It has been subtracted from the constant coefficient.

Table shows that periods of 1997, 2000, 2008 and 2011 have dramatically fallen down into negative values indicating potential impact on the trend of equity premium. It is known that these years are actually the periods of financial crises.

Table 5. Fixed Effects on Countries as Dummy Variables

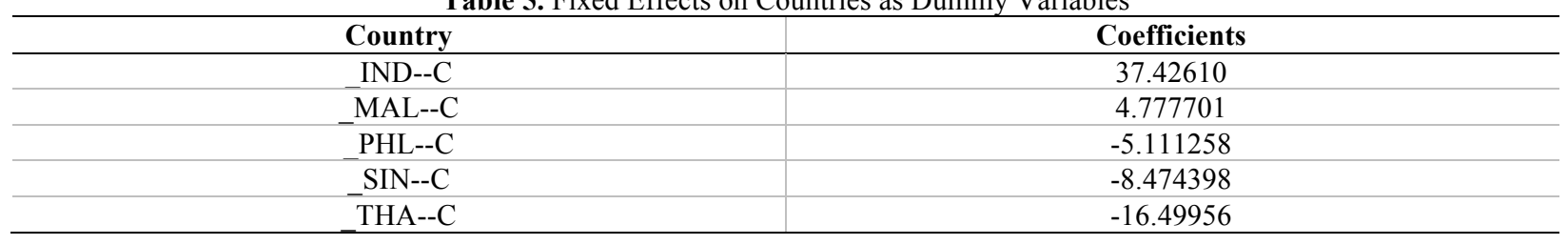

Fixed effects as dummy variables for the entities or the countries also show the existence of the fixed effects of the model. Both Malaysia and Indonesia have shown positive values while the other countries have negative coefficients. This simply means each country has also their individual characteristics and impacts on the dependent variable.

Table 6. Effects Specification of the Model

\begin{tabular}{l|l|l|l}
\hline Cross-section/Period fixed (dummy variables) & & \\
\hline R-squared & 0.837581 & Mean dependent var & 30.35923 \\
\hline Adjusted R-squared & 0.771599 & S.D. dependent var & 49.30871 \\
\hline S.E. of regression & 23.56530 & Akaike info criterion & 9.398858 \\
\hline Sum squared resid & 35540.69 & Schwarz criterion & 10.14384 \\
\hline Log likelihood & -400.6480 & Hannan-Quinn criter. & 9.699411 \\
\hline F-statistic & 12.69397 & Durbin-Watson stat & 1.490711 \\
\hline Prob(F-statistic) & 0.000000 & & \\
\hline
\end{tabular}


Table 6 presents the summary of the effects specification of the panel pooled regression with fixed effects of dummy variables of both time and countries. The adjusted $\mathrm{R}$-squared 0.771599 suggests that almost $77 \%$ variations of the four selected macroeconomic variables such as INF, FDI, GDP and STTR can explain equity risk premium in six major ASEAN members

\subsection{Panel Vector Error Correction Model (VECM)}

Table 7. Stationary Test

\begin{tabular}{|c|c|c|c|c|c|}
\hline \multicolumn{3}{|c|}{ ADF Fisher Chi-square } & \multicolumn{3}{|c|}{ PP- Fisher Chi-square } \\
\hline Series & Level & 1st difference & Series & Level & 1st difference \\
\hline ERP & $36.8536^{* * *}$ & $110.096^{* * *}$ & ERP & $67.4763^{* * *}$ & $125.097^{* * *}$ \\
\hline GDP & $39.1073^{* * *}$ & $116.394^{* * *}$ & GDP & $52.3254^{* * *}$ & $107.337^{* * *}$ \\
\hline INF & 21.4221 & $119.245^{* * *}$ & INF & 30.1690 & $124.352^{* * *}$ \\
\hline FDI & 15.4564 & $86.2404^{* * *}$ & FDI & 15.0383 & $109.391^{* * *}$ \\
\hline STTR & 12.7988 & $63.3060^{* * *}$ & STTR & 11.7283 & $104.687^{* * *}$ \\
\hline
\end{tabular}

Table 7 of stationary test clearly suggests that no unit roots exist among all the variables at their first differences as both ADF and PP test statistic are significant at 1\% level of significance. These probabilities for Fisher tests are accounted by using an asymptotic Chi-square distribution. The results indicate that all variables are integrated and stationary of the same order I (1). But it can be noticed that both ERP and GDP also show to have stationary series starting on their level. In this case, there is no need for these two series to have differences transforming these data into $\log$ would be enough. Thus, all the series do not have unit root and stationary in the first difference.

Table 8. Lag-Order Selection Criteria

\begin{tabular}{c|c|c|c|c|c|c}
\hline Lag & LogL & LR & FPE & AIC & SC & HQ \\
\hline 0 & -1024.208 & NA & $3.32 \mathrm{e}+09$ & 36.11257 & 36.29178 & 36.18222 \\
\hline 1 & -930.5914 & 167.5247 & $3.00 \mathrm{e}+08$ & 33.70496 & 34.78025 & 34.12286 \\
\hline 2 & -884.6084 & 74.21821 & $1.47 \mathrm{e}+08$ & 32.96871 & 34.94008 & 33.73485 \\
\hline $\mathbf{3}$ & -819.1745 & $\mathbf{9 4 . 1 3 2 9 7} *$ & $\mathbf{3 7 4 3 1 2 1 7}$ & 31.54998 & $\mathbf{3 4 . 4 1 7 4 2}^{*}$ & $\mathbf{3 2 . 6 6 4 3 7} *$ \\
\hline 4 & -794.3697 & 31.33230 & 41832595 & 31.55683 & 35.32035 & 33.01946 \\
\hline 5 & -761.5675 & 35.67959 & 38131429 & $\mathbf{3 1 . 2 8 3 0 7 *}$ & 35.94266 & 33.09395 \\
\hline
\end{tabular}

Note * indicates lag order selected by the criterion at $5 \%$ level of significance

After satisfying the condition of series should be stationary and integrated at the same order, it is also a must to determine the lag order before proceeding to Johansen's Cointegration Test. Table 8 shows that lags order at 3 is the appropriate lag order as among the six criterion, four criterion are significant at lag 3 . These criterions are sequential modified LR test statistic (LR), final prediction error (FPE), Schwarz information criterion (SC) and Hannan-Quinn information criterion (HQ).

Result of Johansen Cointegration Test shows one cointegration equation among the selected four macroeconomic variables and the equity premium. It has two approaches of unrestricted cointegration rank tests such as the Trace and maximum eigenvalue. Both of these tests suggest existence of at least one cointegration for the long run relationship among the factors. 
Table 9. Unrestricted Cointegration Rank of Trace Test

\begin{tabular}{l|c|c|c|c}
\hline Hypothecized No. of CE(s) & Eigenvalue & Trace Statistic & $\mathbf{0 . 0 5}$ Critical Value & Prob.** \\
\hline None * & 0.756940 & 122.1661 & 69.81889 & 0.0000 \\
\hline At most 1 & 0.240078 & 33.05606 & 47.85613 & 0.5537 \\
\hline At most 2 & 0.216953 & 15.76005 & 29.79707 & 0.7290 \\
\hline At most 3 & 0.004203 & 0.352608 & 15.49471 & 1.0000 \\
\hline At most 4 & 0.001385 & 0.087293 & 3.841466 & 0.7676 \\
\hline
\end{tabular}

Table 9 shows the results of Trace test indicating at least one cointegrating equation among the variables since the none cointegration hypothesis probability $\left(0.0064^{*}\right)$ is rejected at the 5 percent of signifcance level. These p-values are referred to MacKinnon-Haug-Michels (1999).

Table 10. Unrestricted Cointegration Rank Test of Maximum Eigenvalue

\begin{tabular}{l|c|c|c|c}
\hline Hypothecized No. of CE(s) & Eigenvalue & Max-Eigen Statistic & 0.05 Critical Value & Prob.** \\
\hline None ${ }^{*}$ & 0.756940 & 89.11007 & 33.87687 & 0.0000 \\
\hline At most 1 & 0.240078 & 17.29601 & 27.58434 & 0.5546 \\
\hline At most 2 & 0.216953 & 15.40744 & 21.13162 & 0.2614 \\
\hline At most 3 & 0.004203 & 0.265315 & 14.26460 & 1.0000 \\
\hline At most 4 & 0.001385 & 0.087293 & 3.841466 & 0.7676 \\
\hline
\end{tabular}

Same with the Trace test, the maximum eigenvalue test suggests the existence of one cointegration equation among the five variables. Then one cointegration hypothesis is rejected as the probability is significant at the 5 percent level of significance.

Table 11. Panel VECM with Cointegration equation

\begin{tabular}{l|c|c|c}
\hline \multicolumn{1}{c|}{ Cointegrating Equation } & Coefficient & Standard Errors & t-Statistics \\
\hline ERP(-1) & 1.000000 & & 0.17184 \\
\hline FDI(-1) & 0.958216 & 5.57605 & -5.20075 \\
\hline GDP(-1) & -101.6233 & 19.5401 & $\mathbf{5 . 8 3 9 8 5}$ \\
\hline INF-1) & $\mathbf{3 5 . 2 6 9 7 9}$ & $\mathbf{6 . 0 3 9 5 0}$ & 1.07324 \\
\hline STTR(-1) & 1.196366 & 1.11472 & \\
\hline C & 16.35597 & & \\
\hline
\end{tabular}

Table 11 shows the cointegration equation considering ERP (-1) as 1 and how other variables such as FDI (1), GDP $(-1)$, INF (-1) and STTR (-1) would move to get back on their long run relationship in the system. Among the four variables, only INF (-1) shows significant long run relationship with ERP based on t-statistic value (5.83985) which is greater than 2 . This means that $1 \%$ increase on INF will lead to $35.26979 \%$ increase on the ERP. 
Table 12. Error Correction Terms on ERP

\begin{tabular}{|c|c|c|c|}
\hline Error Correction: & Coefficients & Se & t-statistics \\
\hline CointEq1 & -0.054803 & $(0.01466)$ & {$[-3.73838]$} \\
\hline $\mathrm{D}(\operatorname{ERP}(-1))$ & -0.785485 & $(0.13513)$ & {$[-5.81279]$} \\
\hline $\mathrm{D}(\mathrm{ERP}(-2))$ & -0.813734 & $(0.19735)$ & {$[-4.12327]$} \\
\hline $\mathrm{D}(\operatorname{ERP}(-3))$ & -0.282159 & $(0.19762)$ & {$[-1.42779]$} \\
\hline $\mathrm{D}(\mathrm{FDI}(-1))$ & -2.653796 & $(1.81748)$ & {$[-1.46015]$} \\
\hline $\mathrm{D}(\mathrm{FDI}(-2))$ & -2.607926 & $(1.67888)$ & {$[-1.55337]$} \\
\hline $\mathrm{D}(\mathrm{FDI}(-3))$ & -0.318689 & $(1.72210)$ & {$[-0.18506]$} \\
\hline $\mathrm{D}(\operatorname{GDP}(-1))$ & -1.064209 & $(2.37856)$ & {$[-0.44742]$} \\
\hline $\mathrm{D}(\mathrm{GDP}(-2))$ & 0.016109 & $(1.92987)$ & {$[0.00835]$} \\
\hline $\mathrm{D}(\mathrm{GDP}(-3))$ & -0.299403 & $(1.67128)$ & {$[-0.17915]$} \\
\hline D(INFLATION(-1)) & 3.247077 & $(1.05229)$ & 3.08573] \\
\hline D(INFLATION(-2)) & 2.248393 & $(1.12444)$ & [ 1.99956$]$ \\
\hline D(INFLATION(-3)) & 0.850102 & $(0.94082)$ & {$[0.90357]$} \\
\hline $\mathrm{D}(\operatorname{STTR}(-1))$ & -0.329130 & $(0.24121)$ & {$[-1.36451]$} \\
\hline $\mathrm{D}(\operatorname{STTR}(-2))$ & -0.041978 & $(0.24661)$ & {$[-0.17022]$} \\
\hline $\mathrm{D}(\operatorname{STTR}(-3))$ & -0.136059 & $(0.22830)$ & {$[-0.59597]$} \\
\hline $\mathrm{C}$ & -8.978942 & $(4.30930)$ & {$[-2.08362]$} \\
\hline R-squared & & \multicolumn{2}{|c|}{0.656549} \\
\hline Adj. R-squared & & \multicolumn{2}{|c|}{0.537087} \\
\hline Sum sq. resids & & \multicolumn{2}{|c|}{45275.56} \\
\hline S.E. equation & & \multicolumn{2}{|c|}{31.37278} \\
\hline F-statistic & & \multicolumn{2}{|c|}{5.495911} \\
\hline
\end{tabular}

Table 12 presents the error correction coefficients of all variables on its own lags and the lags of the other variables. The dependent variable is the equity premium and other variables including the cointegration equation relationship are the independent variables. The result suggests that deviations of D(INF (-1)) can significantly affect the deviations of D(ERP) as it's t-statistic is greater than two [3.08573]. This indicates that $1 \%$ deviation on the differenced INF lag 1 could correct by $3.247077 \%$ the long-run equilibrium association with ERP.

Table 13. Granger Casuality Test

\begin{tabular}{|c|c|c|c|}
\hline Null Hypothesis & F-statistic & Probability & Decision \\
\hline FDI does not Granger Cause ERP & 0.51577 & 0.6729 & Do not reject \\
\hline ERP does not Granger Cause FDI & 1.19896 & 0.3172 & Do not reject \\
\hline GDP does not Granger Cause ERP & 1.34116 & 0.2687 & Do not reject \\
\hline ERP does not Granger Cause GDP & 10.9826 & $6 . \mathrm{E}-06^{* * *}$ & Reject \\
\hline INF does not Granger Cause ERP & 3.38948 & $0.0231 *$ & Reject \\
\hline ERP does not Granger Cause INF & 7.91595 & $0.0001 * * *$ & Reject \\
\hline STTR does not Granger Cause ERP & 1.71980 & 0.1721 & Do not reject \\
\hline ERP does not Granger Cause STTR & 0.96992 & 0.4127 & Do not reject \\
\hline GDP does not Granger Cause FDI & 0.44307 & 0.7228 & Do not reject \\
\hline FDI does not Granger Cause GDP & 2.87044 & $0.0406^{*}$ & Reject \\
\hline INF does not Granger Cause FDI & 0.59354 & 0.6208 & Do not reject \\
\hline FDI does not Granger Cause INF & 0.44427 & 0.7219 & Do not reject \\
\hline STTR does not Granger Cause FDI & 1.04840 & 0.3763 & Do not reject \\
\hline FDI does not Granger Cause STTR & 0.67446 & 0.5704 & Do not reject \\
\hline INF doesnot Granger Cause GDP & 0.38932 & 0.7610 & Do not reject \\
\hline GDP does not Granger Cause INF & 3.16307 & $0.0281^{*}$ & Reject \\
\hline STTR does not Granger Cause GDP & 2.16050 & 0.0999 & Do not reject \\
\hline GDP does not Granger Cause STTR & 0.97652 & 0.4085 & Do not reject \\
\hline STTR does not Granger Cause INF & 2.61378 & 0.0575 & Do not reject \\
\hline INF does not Granger Cause STTR & 0.72226 & 0.5419 & Do not reject \\
\hline
\end{tabular}

Note $* 5 \%, * * * 1 \%$ level of signifcance 
After determining the long-run relationship, the short-run relationship is tested through Granger Casuality test. The table above clearly shows that both ERP and INF do granger causes each other at $1 \%$ and $5 \%$ level of significance in the short-run. Moreover, it can be noticed that ERP does granger cause GDP at $1 \%$ level of significance while the latter does granger cause INF at 5\% level of significance. FDI also has a granger cause affect on GDP at 5\%.

\section{CONCLUSION}

Equity risk premium in ASEAN countries varies from the period of 1995-2013, it has dramatically fallen down in the years of 1997 and 2008. This is implying a potential affect of the financial crises on the trend of equity premium.

Panel Pooled Regression results indicate statistically significant impact of inflation and liquidity, the stocks traded turn-over ratio on equity premium of six major ASEAN countries. The fixed effects of periods as dummy variables have shown profound decrease in the average change for the periods of not only 1997 and 2008, but also 2000 and 2011. Fixed effects on entities which are the countries have also presented existence of the fixed effects in the model as individual characteristics of each country have been reflected. Malaysia and Indonesia have positive fixed effects value while the remaining countries accounted negative fixed effects coefficient values.

Based on the Johansen Cointegration Test, there is one cointegration among the five variables which means these factors have long-run relationship. Having at least one cointegration, which is one of the conditions to be satisfied before conducting VECM model, this paper has also able to employ a panel vector error correction model (VECM). It suggests deviations from the long run relationship of inflation lag 1 can relevantly affect in deviations of the equity premium for the next period.

Foreign direct investment and gross domestic product didn't show any significant influence on the values of equity risk premium in both two different methods. Meanwhile the STTR is not a robust factor of equity premium in the second method, rational reason is technically and obviously the difference in two approaches. In the short-run relationship, Granger Casuality Test shows both INF and ERP do grangers cause each other. The latter and FDI also show granger cause affect on GDP which has granger cause on INF.

Thus, inflation is a robust macroeconomic indicator significantly affecting on equity risk premium of the ASEAN countries.

\section{AUTHOR BIOGRAPHIES}

Dr. Soo-Hyun Kim is currently an Assistant Professor of Finance at School of Business Administration of Soongsil University. Prior to Soongsil University, he worked for Samsung Asset Management as a quantitative strategist. He holds B.A. in Economics from Seoul National University, and M.A. both in international economics and statistics. He completed his Ph.D. degree in industrial engineering (applied statistics for finance) at Georgia Institute of Technology. Email: soo_hyun.kim@ssu.ac.kr

Katherine Villalobos is a Filipino Scholar and a Ph.D. candidate of Business Administration major in Financial Management at Soongsil Graduate School, South Korea. She holds her Master's Degree in Business Administration from Kangnam University, South Korea and a Bachelor's Degree in Economics (magna cum laude) from Polytechnic University of the Philippines. She is an active member and former Business Manager of Filipino Scholars Organization in South Korea (PIKO). She is currently one of the Seoul City International Student's Ambassadors. Her main research interest is equity risk premium. Email: kantilin@gmail.com

\section{REFERENCES}

Abel, A. B. (1990). Asset Prices under habit formation and catching up with the Joneses. A.E.R. Papers and Proceedings 80, 3842.

Bansal, R. \& Coleman, J. W. (1996). A monetary explanation of the equity premium, term premium and risk free rate puzzles. Journal of Political Economy, 104, 1135-1171. 
Barberis, N., Huang, M. \& Santos, T. (2001). Prospect theory and asset prices. The Quarterly Journal of Economics CXVI (1), 153.

Barro, R. (2006). Rare disasters and asset markets in the twentieth century. Quarterly Journal of Economics, 121, 823-866.

Barro, R., Nakamura, E., Steinson, J. \& Ursa, J. (2009). Crises and Recoveries in an Empirical Model of Consumption Disasters. Working Paper.

Bekaert G., Harvey, C. R., \& Lundblad, C. (2006). Liquidity and Expected Returns: Lessons from Emerging Markets. The Review of Financial Studies.

Brandt, M. W. \& Wang, K. Q. (2003). Time-varying risk aaversion and unexpected inflation. Journal of Monetary Economics, $50,1457-1498$.

Campbell, J. Y., (2003). Consumption-based asset pricing in George Constantinides, Milton Harris, and Rene Stultz (ed.). Handbook of the Economics of Finance. North Holland-Amsterdam, Chapter 13, 803-887.

Campbell, J. Y. (2001), “Asset Pricing at the millennium,” Journal of Finance, 55, 1515-1567.

Campbell J. Y., \& Cochrane, J. H., (1999). By force of Habit: A consumption based explanation of aggregate stock market behavior. Journal of Political Economy, 107, 205-251.

Chen, Z. \& Epstein, L. (2002). Ambiguity risk and asset returns in continuous time. Econometrica, 70 (4).1403-1443.

Constantinides, G. M., Donaldson, J. B. \& Mehra, R. (2002). Junior can't borrow: A new perspective on the equity premium puzzle. Quarterly Journal of Economics, 118, 269-296.

Constantinides, G. M. (1990). Habit formation: A Resolution of the equity premium puzzle. Journal of Political Economy, 98 , 519-543.

Constantinides, G. M. \& Duffie, D. (1996). Asset pricing with heterogeneous' consumers. Journal of Political Economy, 104, 219-240.

Eistein, L. G. \& Zin, S. E. (1991). Substitution, risk aversion, and the temporal behavior of consumption and asset returns: An empirical analysis. Journal of Political Economy, 99, 263-286.

Gibson, R. \& Mougeot, N. (2004). The Pricing of Systematic Liquidity Risk: Empirical Evidence from the US Stock Market. Journal of Banking and Finance, 28, 157-78.

Gul, F. (1991). A theory of disappointment aversion. Econometrica, 59-3, 667-686.

Hansen, L. P., (1982). Large Sample Properties of Generalized Method of Moments. Econometrica, 57, 1029-1054.

Kahneman, D. \& Tervsky, A. (1979). Prospect Theory: An analysis of decision under risk. Econometrica, 47-2, $263-292$.

Karthik, R. \& Kannam, N. (2011). Impact of Foreign Direct Investment on stock market development: A Study With Reference To India. International Journal of Management, Vol 2-2, 75-92.

Lau, S. T., Ng, L. \& Zhang, B. (2011). Information Environment and Equity Risk Premium Volatility around the World. Management Science Forthcoming.

Lettau, M., Ludvigson, S. C. \& Wachter, J. A. (2008). The Declining Equity Risk Premium: What role does macroeconomic risk play?. Review of Financial Studies, 21, 1653-1687.

McGrattan, E. R. \& Presscott, E. C. (2003). Average debt and equity returns: Puzzling?. American Economic Review, 93, 392397.

Mehra, Rajnish; Prescott, Edward C. (1985). The Equity Premium: A Puzzle. Journal of Monetary Economics, 15 (2): doi: 10.1016/0304-3932 (85) 90061-3, 145-161.

Mehra, Rajnish, Edward C. Prescott (2003). The Equity Premium Puzzle in Retrospect. In G.M. Constantinides, M. Harrisand R.Stulz, Handbook of the Economics of Finance, Amsterdam: North Holland ISBN978-0-444-51363-2, 889- 938.

Mehra, R. \& Prescott, E.C. (2007). Intermediated quantities and returns. Working Paper, UCSB.

Mehra, R. \& Prescott, E. C. (2008a). The equity premium: ABC's. In: R. Mehra (ed). Handbook of the Equity Risk Premium, Elsevier, Amsterdam.

Mehra, R. \& Prescott, E. C. (2008b). Non-Risk Based Explanations of the Equity premium. In: R. Mehra (ed): Handbook of the Equity Risk Premium, Elsevier, Amsterdam.

Modigliani, Franco \& Cohn, Richard. (1979). Inflation, Rational Valuation and the Market. Financial Analysts Journal, 37 (3), 24-44.

Pastor, L. \& Veroseni, P. (2011). Uncertainty about government policy and stock prices. Working paper

Ramaprasad, Bhar \& Malliaris, A. G. (2011). Dividends, Momentum and Macroeconomic Variables as Determinants of the U.S. Equity Premium Across Economic Regimes. Review of Behavioral Finance, Department of Economics and Finance, Loyola University of Chicago

Rietz, T. A. (1988). The Equity risk premium: A solution. Journal of Monetary Economics, 22, 117-131.

Roelof, Salomons \& Grootveld, Henk. The Equity Risk Premium: Emerging versus Developed Markets. University of Groningen and AEGON Asset Management, Netherlands, Robeco Group.

Routledge, B. \& Zin, S. (2004). Generalized Disappointment Aversion and Asset Prices. Mimeo: Carnegie-Mellon University.

Samira, Allahyari Westlund, Sheludchenko, Dmytro, \& Tahmidi, Arad, (2011). The effect of Macroeconomic Variables on Market Risk Premium. School of Sustainable Development of Society and Technology, Malardalen University

Stock, J. and Watson, M. W. (2003). Introduction to Econometrics. New York: Prentice Hall

Tarum, Chordia, Subrahmanyam, Avanidhar and Anshuman, V. Ravi (2001). Trading activity and expected stock returns. 
Journal of Financial Economics, 59, 3-32.

Vladimir Arcabic, Tomislav Globan \& Irena Raguz (2012). The relationship between the stock market and foreign direct investment in Croatia: evidence from VAR and coitegration analysis. University of Zagreb, Faculty of Economics and Business

Yee, K. K. (2006). Earnings Quality and the Equity Risk Premium: A Benchmark Model. Contemporary Research, 23, 833-877. Website: ASEAN UP (2012). Empowering business in Southeast Asia. Retrieved from the ASEAN Information graphics Online Website: http://aseanup.com/asean-infographics-population-market-economy/ 